\title{
CONFLICTS OF INTEREST IN PAKISTAN AND UNITED STATES RELATIONS (2008-2019)
}

\author{
Saima Parveen* \& Syed Akhtar Ali Shah $\uparrow$
}

\begin{abstract}
The ambit of Pakistan's relationship with the United States is based on convergence as well as divergence of interests, whereby the United States kept intense engagement followed by periods of utter indifference. Most of the times mutual mistrust and suspicions makeshift the policy parameters to the strategic impasse. Considering the trends of the relations, the US policy revolves around the struggle for global hegemony with policy parameters of off-shore balancing and buck-passing, and Pakistan is mainly focused on security imperatives. This piece of research investigates that what are grounds of conflicts between Pakistan and the United States relations? The study is conducted by explanatory and analytical approaches. Data sources are both primary and secondary where for primary source data was collected through Interviews with ministry of defence and foreign office. The United States and Pakistan relations remained uneasy due to mistrust and accusations and the US preference to India in the region in general and in Afghanistan in particular and the China's growing influence in the region. The need is to understand Pakistan's security concerns, an acknowledgment of the contribution to the war against terror and above all to revive cooperation for regional peace and prosperity.
\end{abstract}

Keywords: Conflicts, Strategic, Peace, Terrorism, National Sovereignty.

\section{Introduction}

Foreign policy revolves around national interests and in the domain arises mistrusts, doubts and consequently accusations. In international

\footnotetext{
Assistant Professor, Political Science at Women University Swabi.

${ }^{+}$Former Home Secretary, Khyber Pakhtunkhwa.
} 
politics the relationships have had conflicts manifested in periods of engagement, followed by periods of coldness and that what happens in the United States relations with Pakistan. For Pakistan, the issues of security and survival, in a turbulent and hostile regional environment, have been the overriding policy factors in its relations with Washington. The US' policy goals in Pakistan, on the other hand, have traditionally been rooted in its own regional and global interests, specifically issues of nuclear and missile proliferation, issues of democracy, human rights, economic reforms, terrorism, Indo Pakistan rivalry, Afghanistan and currently its China-driven agenda.

Major US engagements with Pakistan occurred during the height of the Cold War period, from the mid-1950s to mid-1960s, where Pakistan-US relations remained exceptionally good. These good relations were due to mutual interests as the United States needed an ally to counter communism in both South East Asia and in Middle East and Pakistan was part of Northern Tier which could assist in the US counter-Communism containment policy. Pakistan due to security imperatives was in need of economic and military aid and the US was only promising source for the said assistance. The second was during the Afghan Jihad in the 1980s, where US need Pakistan to defeat former Soviet Union; the third one is Pak US collaboration during war on terror and the current engagement that is still ongoing with Pakistan being kept hostage to US' China-driven agenda in the region.

This research article illustrates grounds of conflicts in Pakistan relations with the United States which is mainly based on firstly, mistrust and blame game in Afghanistan, secondly, US preference to India in the region of south Asia and thirdly, due to China's growing influence in the region and uneasiness of the US towards China Pakistan Economic Corridor (CPEC).

\section{Mistrust and Blame Game in Afghanistan Perspectives}

Pakistan has paramount significance in the region due to its geostrategic location. Pakistan has been bordered with Afghanistan, India, Iran and China. The United States covetously chased Pakistan for numerous objectives to be fulfilled. The US persistently used Pakistan's political influence and intelligence sectors to trample Al-Qaeda's sanctuaries and high command and furthermore to hamper new recruitments or flourishing of Al-Qaeda. (Fair, N.D)

Basically, Pakistan is geographically very significant as providing transit access to Afghanistan hence after 9/11 the US asked Pakistan for intelligence and logistics help in its ANACONDA military operation inside Afghanistan. Pakistan played a frontline state role.

Pakistan became indispensable for the US war in Afghanistan as Pakistan's air bases and transit routes were used for transit of US stocks to the troops in Afghanistan. Pakistan assistance is always asked by the US in 
controlling and other violent entities who have been causing casualties to the foreign forces by deadly attacks.

Although the role is played by Pakistan who has suffered in form of thousands deaths and a huge cost to its whole fabric. Pakistan military has had launched several military operations both in FATA and PATA because both the areas were strewn with militants. Hence major military operations like Rah-e-haq, Rah-e-Raast and Zarb-e-Azb have been conducted in order to overcome the militancy. But in spite of Pakistan's efforts the US had accused Pakistan role where the Inter Service Intelligence Directorate (ISI), has been labelled as - rogue, harboring and backing Taliban and militants.

Moreover, the ISI is alleged for hypocrisy by Ahmad Rashid with vehement conviction that ISI has established an NGO type institutional body which operates Taliban's missions and composed of the Retired military officers among whom General Hameed Gul was specially named. CIA and MI5 interrogated Hameed Gul but nothing came to the surface. The US intelligence officers stated that Taliban were patronized by ISI officers. (Rashid, 2008) Musharraf government had, despised these allegations, butconceded with the presence of safe haven for the extremists elements. It has been conceded by the US administration concerned personnel that Pakistan is not the main cause of Afghanistan turmoil. This issue as former security advisor of Bush emphasized, that the key to Afghanistan insurgency lies in Afghanistan, not Pakistan. (Kilkullin, 2009)

What to say of blame game and allegations the US has had unilaterally attacked and entered into Pakistan territory and violated its national sovereignty by drone strikes. The violation has led to anti-American sentiments. (Ahmad, 2012)

The instances of major violation of national sovereignty and territorial integrity has been happened in the timeline of governments of Barak Obama in the US and President Zardari in Pakistan. The very first episode was in form of Raymond Davis, a private contractor, a secret CIA blackwater agent who roamed and killed two persons in Lahore. His very presence was violation of national sovereignty. Keeping him in detention caused resentments in the US and the chances for strategic dialogues diminished with low ebb in bilateral relations. Later on with huge diplomatic pressure Raymond Davis was set free whereas the US applied for his diplomatic immunity. This episode was followed by another violation of national sovereignty territorial integrity in form of the US unilateral attack inside Pakistan in operation Naptune Spear in compound in Abbottabad on May 2, 2011 where according to the US Osama Bin Laden was residing. Killing him was not ground of concern for Pakistan but the US unilateral raid was resented by Pakistani authorities.

It was not only violation of national sovereignty but of international law also in the case of Blackwater and Shakil Afridi. The later has played the role of the US spy in investigating the whereabouts of the OBL and 
confirming him in the compound. The spying for foreign intelligence is great treason and is against the Penal code provision. Another related incident can be quoted from the US history of 1985 in the case of Mr. Jonathan Pallard who was arrested by the US for spying of Israel intelligence and consequently was punished for life. He defended his spying for the purpose of making US-Israel relations cordial but no any relief was granted to him in spite of the Israel approach and request to the US for him. Joe Biden on the Netanyahu threatening to the US bluntly refused any of the favor to the Pallard. (Sheikh, 2012) Another more shocking episode added when the US forces fired for hours on Salala check post situated in Mohmand Agency (currently district of KP). The US tried to cover the firing on the ground that mortar fires were attacked from this check post on its forces and it took it as an attack by Afghan violent forces.

To the utter dismay, this checkpost was already marked with consensus of coalition forces hence no any ignorance of the check post could have been an excuse. On this point Pakistan reacted by taking some stern steps as blocking the NATO supply line, Shamsi air base was evacuated and boycotted attending the Bonn conference. (Kronstadt, 2008)

These have been major instances of violation of national sovereignty and territorial integrity whereas the repeated violation has happened in the shape of drone strikes in FATA which has caused mistrust in bilateral relations. (Bruno, 2010) The US defends the strikes on grounds that she cannot trust the role of Pakistan in handling the drones strike because the Pakistan soil has several militants sanctuaries from where the insurgents can attack on US and other foreign forces inside Afghanistan. Rashid, 2008)

The US drone strikes inside Pakistan has given emergence to antiAmerican sentiments and the complicit role of Pakistan's government. These strikes have caused huge resentment in Pakistan and has yielded in dire consequences for Pakistan, the fact recognized by the US officials Munter and David Patraeus even. (Ignatius, 2012)

After the president Obama the Republican candidate Donald Trump became the president who in his first half presented the South Asia Policy, where he was adamant towards Pakistan. He continued the same covert coercive strategy. The drone policy followed by president Trump has widened the gap between the two states even further. (Luce and Naylor, 2018) Furthermore, the Trump South Asia policy had caused more disengagement by accusing Pakistan and blamed it for keeping militants safe-havens. The same repeated in his 2018 New Year day tweet accusing Pakistan of 'lies and deceit' followed by impeding transfer of 300 million dollars to Pakistan under the Coalition Support Fund (CSF) by citing ineffectiveness of Pakistan against terrorism as ground (Malik, 2018) ceased military training for defence personnel, resorted to the use of diplomatically harsh language and exercised its influence in the Financial Action Task Force (FATF) to put Pakistan on its grey list. The US has repeatedly echoed 
that the process followed and implemented by Pakistan is slow, leading to inevitability of the imposition of sanctions. (Iqbal, 2018) Pakistan on the other hand, maintains that its efforts and sacrifices in the global fight against terrorism go unacknowledged. The US disregard of Pakistan's sensitivities, its legitimate security interest vis-à-vis these states has not helped to bridge the mistrust in their relationship.

The Americans, in particular, now merely view this relationship on the basis of finding an acceptable solution to the Afghan conundrumAfghanistan has, unfortunately, become the sticking point in Pak-US relations. On the other hand, Pakistan seeks a balanced relationship that will ultimately lead to peace and reconciliation in Afghanistan without compromising on its national security concerns.

\section{Preferential treatment of India in Post 9/11 Decades}

The United States deems this region very significant in its geo-political priorities of containment of China and post 9/11 new great game in Central Asian Republics (CARs). The US grand strategy revolves around strategic and economic dimensions in the region. India role matter the most in regional perspectives whereas multi-billion military pact has been signed between the US and India. The preferential role to the India has been destabilizing the regional security parameters. The US has made nuclear deal with India. India wants to access the natural resources of CARs and to have working trade and feasible infrastructure and transportation in Afghanistan. Indian role os required for the US in order to counter China assertiveness in the region and specially to curtail Beijing influence in CARs. (Pant, 2010)

In US policy parameters the large Indian population and size and its promising market is alluring. India plays pivotal role in containment of China in Indian Ocean and Straits of Hormuz. (Khan, 2015) The US through Nuclear Supply Group has provided military weapons and other defence assistance to the India. The United States wanted the Indian dominancy in Central Asian Republics in order to counter the Beijing and Moscow influences there. The China assertive economy is apprehensive for the US and the Indian preferential treatment in these decades after 9/11 is mainly due to these grounds.

In the perspective of Afghanistan, after the US troops withdrawal the vaccum created is wanted to be filled by the India rather than Pakistan because the US underlying policy contours needs to have a regional country to contain the aspiring power. Through buck passing strategy the US wanted Indian presence to play her role for the US so that China regional hegemonic designs can be curbed. Accordingly the India-Afghanistan security cooperation has been supported by the US.

Afghanistan has been important for India after 1990s with world structure became unipolar. The special attention towards Afghanistan was after 9/11 in general and in October 2011 in particular by signing strategic 
partnership agreement. India has foreign policy objectives to have infrs investment inside Afghanistan is to secure herself after the withdrawal of foreign forces and to ensure her hegemonic designs. (Fair, 2011) India has huge investment in Afghanistan infrastructure and provides military training. Indian consulates in Afghanistan are taken as acting against Pakistan as several intelligence agencies operate there to have destabilizing activities inside Balochistan from over there and which are active to instigate separatist tendencies in Baluch population against Pakistani state. The Indian presence has promoted its diplomatic interests which has caused huge damage to Pakistan. (Hussain, 2012)

In fact such strategic dominance of India is leading regional power imbalance. The Indian four consulates in Herat, Qandahar, Mazari Sharif and Jalalabad are alarming to the national interests of Pakistan because it gives India a nexus with Afghanistan which can inflict costs for Pakistan in general and to Balochistan in particular as happened in case of Kalbushan Jadev who was funding the separatist elements in Baluchistan for giving a deadly blow to the Pakistan's state.

The US has developed strategic partnership with India. The US has accorded a significantly more prestigious treatment to New Delhi by recognizing it as the regional pivot in South Asia to serve its interests. This geostrategic recognition has a lot to do with its rising economic power. At the same time, Pakistan increasingly is taken as perpetrator of terrorism in the region and an inherently unstable state. (Constable, 2017)The US not only ignores Pakistan, it has tilted the regional balance in favor of India by offering it a civil Nuclear Deal irrespective of the fact that it is not a signatory of the Nuclear Non-Proliferation Treaty (NPT). (Bajoria and Pan, 2010) The 2018 2-plus-2 Dialogue (where the COMCASA, or Communications Compatibility and Security Agreement was signed), Washington's all-out efforts and lobbying for India to gain access to nuclear regimes are few examples in this regard.

Taking Pakistan role for the US then Pakistan could not achieve through this relationship, as it could not negotiate on Kashmir beyond a certain point. Furthermore, it could neither achieve nuclear normalization the way India is being accommodated. The alliance partnership as per its fundamentals was naturally tilted in favour of the superior partner, because of which Islamabad could not benefit from deals akin to the Indo-Soviet treaties that ultimately benefitted New Delhi more. Viewing this scenario from a realistic lens, Pakistan also did not extract the maximum benefit from this arrangement. With repeated opportunities such as the 1962 Indo-China War, US-Chinese rapprochement, the decade-long Afghan war, and even the reengagement post-9/11, Pakistan could have sought better leverage. The US was happy to court New Delhi, as its proxy in the South Asian region as well as challenger to China. 
The 2019 Indian false flag operation in Pulwama and its staged surgical strikes across the Line of Control, has brought home the acute realization that such adventurism for limited domestic gains, could have easily slipped the two countries into a nuclear catastrophe, had Pakistan not acted with utmost restraint and caution. The US and world community did indulge in brokering peace, but there was no open sanctioning of India over this costly mischief, that endangered the lives of one fourth of humanity. Had Pakistan indulged in such a misadventure, the US reaction would have been much different.

\section{Chinese ingress in the area, Alarming to the US}

The US grand strategy is to counter Russia and China influences in Asian region. Although, in future the countries Russia, Pakistan and China will be key players in in exploitation of natural resources and the regional power paradigm will be tilted towards the Russia and China.

China military and economic assertiveness is apprehensive for the US hence the US is militarily active in East Asia. The China export and imports through Malacca Strait is facing impdiments due to the US and India where both see China as immediate threat for them. Chinese economy is anticipated to grow at double rate of the US ones over next 15 years. According to RAND, Beijing is $40 \%$ of the US which is envisaged as half of that till 2025. China's $2.5 \%$ of GDP is specified to defence expenditures. Chinese defence spending by 2025 will probably reach more than US due to its focus on Western Pacific whereby the handful of US will there. (Crane et al. 2011)

China is focused on keeping Pakistan economically and politically stable. Pakistan is strategic opening to the Arabian Sea due to its Gwadar port which can facilitate China with shortest route to the world markets. Through which China will escape the Malacca Straits dilemma. More, it will counter the US and India threats in Indian threats. Importantly the Indian hegemonic designs can be curbed when both Pakistan and China connected in strategic ties.

Pakistan, in the face of being side - lined by the US, has all through its existence sought the support of China to balance its national interests, primarily to counter India's expansionist designs. As stated above, China has proven to be a considerably trustworthy ally of Pakistan and their cordial partnership over decades is evident in the China-Pakistan Economic Corridor (CPEC), a 60 billion dollars-plus economic engagement over infrastructure and energy. (Zheng, 2018) The US has always been wary of cooperation between the two, and believes that Pakistan's role as a linchpin to Beijing's Belt and Road Initiative (BRI) would essentially distract it from its responsibilities to curb terrorism in the region, contain nuclear proliferation and bring a decisive end to the Afghan instability. (Markey and West, 2016) 
The China-Pakistan Economic Corridor (CPEC) and development of the Gwadar port has received enormous negative press by the US, an aspect that has been fully exploited by New Delhi. The US, threatened by the growing Chinese presence, through the Belt and Road Initiative (BRI), has and will in the future actively encourage an increased Indian naval presence in the Indian Ocean as a force multiplier. With its growing nuclear triad, nuclearisation of Indian Ocean would further destabilize the region and fuel an arms race that would pitch many current allies against each other in the future.

The Neo-Realism off shoot, Offensive Realism presented by Mearsheimer has main provision that there can only be regional hegemon. To become global hegemon the state will continuously struggle for power maximization. The US according to John Mearshiemer strives to become global hegemon but there are several impediments in its way of global hegemony as water and geography. The offensive realism includes strategy of off-shore balancer and buck passing. The off-shore balancer role of US was in North East Asia and Europe where the US kept its military bases there. (Mearsheimer, 2001) The regional hegemon is also focused on aspiring hegemon for which purpose the role of other regional players is also required. In buck passing strategy the regional hegemon while being keeping itself in background watch on aspiring hegemon and if needed then invade the region militarily to counter peer competitors. The US in order to become global hegemon is giving preferential treatment to the India in order to counter the aspiring hegemon like China and Russia. Thus the US is to become hegemon in Central Asia and South Asia. The US through India is focused on to counter Moscow and Beijing influences in Central Asia.

\section{Recommendations}

- Both states need to primarily cooperate for defeating terrorism and to focus on mutual interests rather than divergence. An institutional mechanism may be developed to align their perceptions and policies with each other.

- The ambit of bilateral relations encompassed working for regional prosperity and connectedness from position of strength rather than compromises.

\section{The United States}

- Needs to acknowledge Pakistan paramount role in having leverage for the US in its relations with the Taliban, China as well as in case of China relations with India.

- With the US the relationship of Pakistan needs to be a normal and working relations rather than mere transactional and the trajectory may not be limited to the War on Terror only. 
What Pakistan needed is

- In case of Afghanistan Pakistan long term policy stand is a unified, stable and friendly Afghanistan with no investment in any individual, faction or group. Afghanistan is sovereign country to decide its own relations but those relations may not be detrimental to the very interests of Pakistan.

- The Pakistan image be of a growing economy interested in regional engagements and agreement and is open to attracting investments from other countries. This is imperative because it projects an image of the country where a liberal, middle class leads political processes and the 'Homeland' image of Pakistan as a preserve of Islamist radicals and extremist groups is de-emphasized.

- Pakistan needs to prompt a (re)think in its foreign policy practices, and formulate a doctrine which clearly pursues its national interests without compromising to other states and their self-interest driven propagandas. In order to secure its national interests, it is pragmatic to diversify options for support and alliances in the international political system.

\section{Conclusion}

In view of Pak-US relations, the conflicts in bilateral relations are due to mistrust and blame game. Pakistan has played key role in post 9/11 decades in war on terror and has suffered as thousands lives have been lost and Pakistan security has been shaken. The US instead has doubted Pakistan role for most of the time in war on terror whereby Pakistan is accused for providing sanctuaries to the militants. Pakistan and the US relations are conflict driven mainly due to Indian factor because the US wants a dominant role for India both in Afghanistan and in CARs in order to counter China rise. What Pakistan wants is that both Pakistan and India be treated equally as equal sovereign powers in South Asia. The China Pakistan cooperation is causing uneasiness in both the US and India hence both are busy in promoting strategic partnership. Both US and Pakistan need to have relations based on trust and to develop institutional level working relationship in order to ensure regional peace and prosperity.

\section{References}

Ahmad, S. (2012). Impending Afghanistan Stalemate. 18 December, 2012. Bajoria, J. and Pan, E. (2010). 'The U.S.-India Nuclear Deal', New York: Council on Foreign Relations.

Bruno, G. (2010). 'U.S. Drone Activities in Pakistan', New York: Council on Foreign Relations.

Constable, P. (2017). 'Pakistan, Accused of Terrorist Infiltration, Starts to Fence its Border with Afghanistan', The Washington Post. 
Crane et al. (2005). Modernizing China's Military: Opportunities and Constraints (Santa Monica, CA: RAND), Wolf et al.(2011) China and India 2025: A Comparative Assessment (Santa Monica, CA: RAND, 2011)

Fair, C. (2011). Under the Shrinking US Security Umbrella: India's End Game in Afghanistan. The Washington Quarterly, Taylor and Francis.p. 180.

Fair. C.C. (N.D) Pakistan: Can the United States Secure an Insecure State? Santa Monica: RAND Corporation.

Hussain, S. (2012). Issues and Challenges in Pakistan-Afghanistan Relations after 9/11. South Asian Studies.Vol 27. No1. p. 93.

Ignatius, D. (2012). An Embassy Asks, Drones or Diplomacy? Washington Post, June 12, 2012.

Iqbal, A. (2018). 'Pakistan's Effort to end Terrorist Financing remains Uneven: US', Dawn.

Kilkullin, D. (2009). The Accidental Guerila. Oxford University Press.p.53.

Kronstadt, A.K. (2008). Pakistan-US Relations. Report RL 33498 (Washington, DC: CRS.

Khan, A. (2015). Former Chief Secretary of Khyber Pakhtunkhwa, Interview with Author. 26 ${ }^{\text {th }}$ August 2015.

Luce, D.D. and Naylor, D.S. (2018). 'The Drones are Back', Foreign Policy, 26 March, .2018.

Malik, A.J. (2018). 'Pak-US Relations: America Continues Demanding 'do more' even from Imran Khan', Dunya News.

Markey, S.D. and West, J. (2016). 'Behind China's Gambit in Pakistan', New York: Council on Foreign Relations.

Mearsheimer, J.J. (2001). Tragedy of Great Power Politics. New York: Norton. p. 389.

Najmuddin A. Sheikh, A.N. (2012). Points of Contention. Dawn Newspaper.

Pant, V.H. (2010). India in Afghanistan: A Test Case for a Rising Power. Contemporary South Asia. Vol 18. No 2. 2010. p. 147.

Rashid, A. (2008). Descent into Chaos. New York and London: Viking. pp. 222-3.

Schaffer, C.T. and Schaffer, N.H. (2011). 'How Pakistan Negotiates with the United States: Riding the Roller Coaster', Washington, D.C.: United States Institute of Peace, 2011.

Zheng, S. (2018). 'Is China's US\$62 Billion Investment Plan fuelling Resentment in Pakistan? 'South China Morning Post. 